\title{
miR-15a/miR-16-1 expression inversely correlates with cyclin D1 levels in Men1 pituitary NETs
}

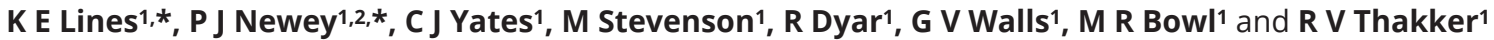

${ }^{1}$ Academic Endocrine Unit, Radcliffe Department of Medicine, University of Oxford, Oxford Centre for Diabetes, Endocrinology and Metabolism (OCDEM), Churchill Hospital, Headington, Oxford, UK

2Division of Molecular \& Clinical Medicine, University of Dundee, Ninewells Hospital \& Medical School, Dundee, UK

Correspondence should be addressed to R V Thakker: rajesh.thakker@ndm.ox.ac.uk

*(K E Lines and P J Newey contributed equally to this work)

\begin{abstract}
Multiple endocrine neoplasia type 1 (MEN1) is an autosomal dominant disorder characterised by the combined occurrence of parathyroid, pituitary and pancreatic islet tumours, and is due to mutations of the MEN1 gene, which encodes the tumour suppressor protein menin. Menin has multiple roles in genome stability, transcription, cell division and proliferation, but its mechanistic roles in tumourigenesis remain to be fully elucidated. miRNAs are non-coding single-stranded RNAs that post-transcriptionally regulate gene expression and have been associated with tumour development, although the contribution of miRNAs to MEN1-associated tumourigenesis and their relationship with menin expression are not fully understood. Alterations in miRNA expression, including downregulation of three putative 'tumour suppressor' miRNAs, miR-15a, miR-16-1 and let-7a, have been reported in several tumour types including non-MEN1 pituitary adenomas. We have therefore investigated the expression of miR-15a, miR-16-1 and let-7a in pituitary tumours that developed after 12 months of age in female mice with heterozygous knockout of the Men1 gene (Men1+/- mice). The miRNAs miR-15a, miR-16-1 and let-7a were significantly downregulated in pituitary tumours (by 2.3-fold, $P<0.05 ; 2.1$-fold $P<0.01$ and 1.6-fold $P<0.05$, respectively) of Men $1^{+/-}$mice, compared to normal WT pituitaries. miR-15a and miR-16-1 expression inversely correlated with expression of cyclin D1, a known pro-tumourigenic target of these miRNAs, and knockdown of menin in a human cancer cell line (HeLa), and AtT20 mouse pituitary cell line resulted in significantly decreased expression of miR-15a $(P<0.05)$, indicating that the decrease in miR-15a may be a direct result of lost menin expression.
\end{abstract}

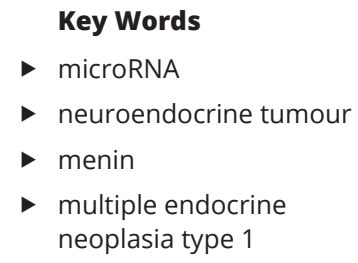

Journal of Endocrinology (2019) 240, 41-50

\section{Introduction}

Multiple endocrine neoplasia type 1 (MEN1) is an autosomal dominant disorder characterised by the combined occurrence of parathyroid, pituitary and pancreatic islet tumours (Pieterman et al. 2009, Goudet et al. 2010, Thakker et al. 2012, Frost et al. 2018). MEN1 is due to mutations of the MEN1 gene, which encodes the tumour suppressor protein menin (Chandrasekharappa et al. 1997, Concolino et al. 2016, Lemos \& Thakker 2008, https://joe.bioscientifica.com https://doi.org/10.1530/JOE-18-0278 (c) 2019 The authors Published by Bioscientifica Ltd. Printed in Great Britain

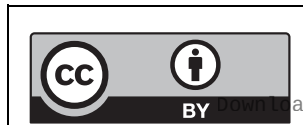

This work is licensed under a Creative Commons Attribution 4.0 Unported License. 
Lemmens et al. 1997). Loss of menin expression is observed in the majority of MEN1-associated tumours, in keeping with Knudson's two-hit model of inherited tumourigenesis (Chandrasekharappa et al. 1997, Concolino et al. 2016, Lemos \& Thakker 2008, Lemmens et al. 1997). Menin is involved in a diverse range of cellular processes including: transcriptional regulation, genome stability, cell division and proliferation (Thakker et al. 2012, Frost et al. 2018). However, the mechanisms by which menin loss results in tumourigenesis are not fully understood. One mechanism that is likely to be implicated involves miRNAs, which have been reported to have roles in the development of a large number of other tumour types (Filipowicz et al. 2008, Stefani \& Slack 2008). Moreover, menin has been reported to regulate the expression of miRNAs (Luzi et al. 2012a,b, Wang et al. 2013, Gurung et al. 2014, Li et al. 2014, Ouyang et al. 2015, Ehrlich et al. 2017, Hou et al. 2017), which are short, non-coding, single-stranded RNAs that post-transcriptionally regulate gene expression, predominantly by imperfect base pairing to the 3' untranslated region (UTR) of target mRNA sequences (Filipowicz et al. 2008, Stefani \& Slack 2008). The importance of miRNAs has been illustrated by their ability to influence a wide spectrum of cellular processes including proliferation, apoptosis and differentiation, in a tissue-specific manner and many miRNAs have been implicated in tumour development through the ability to influence the expression of a diverse set of target genes, including tumour suppressors and oncogenes (Peng \& Croce 2016).

The role of miRNAs in pituitary tumourigenesis has been investigated by microarray-based profiling studies, which have revealed changes in their expression (Wierinckx et al. 2017). For example, sporadic human pituitary tumours have been reported to have altered expression of multiple miRNAs, when compared to normal pituitary tissue (Bottoni et al. 2005, 2007, Amaral et al. 2009, Qian et al. 2009, D'Angelo et al. 2012, Palmieri et al. 2012). The functional significance of such changes in miRNA expression in endocrine tumourigenesis, especially in relation to MEN1-associated pituitary tumours remains unknown. It has however been demonstrated that the putative tumour suppressor miRNAs miR-15a, miR-16-1 and let-7 are downregulated in non-functioning adenomas, prolactinomas, somatotrophinomas and corticotrophinomas and that loss of miR-15a and miR-16-1 correlates with increased tumour diameter, while loss of let-7 expression is correlated with increased tumour grade (Bottoni et al. 2005, 2007, Amaral et al. 2009, Qian et al. 2009, D'Angelo et al. 2012, Palmieri et al. 2012).
The specific genetic targets of these miRNAs in pituitary neuroendocrine tumours have not been elucidated, but studies in chronic lymphocytic leukaemia (CLL) have shown that loss of miR-15a and miR-16-1, which co-occur as a cluster, allows overexpression of BCL2, while investigations in prostate and non-small-cell lung cancer have reported that downregulation of miR-15a and miR-16-1 results in increased cyclin D1 (CCND1) expression, with each contributing to tumour formation (Cimmino et al. 2005, Bonci et al. 2008, Calin et al. 2008, Bandi et al . 2009, Croce 2009, Salerno et al. 2009). Similarly, in nonendocrine tumours members of the let-7a family have been shown to target the oncogenes KRAS, MYC and HMGA2 (Johnson et al. 2005, Mayr et al. 2007, Kumar et al. 2008) in a tumour-specific manner. In addition, menin has been reported to directly regulate the expression of miRNA genes via its role as a transcriptional regulator or through miRNA processing (Luzi et al. 2012a,b, Wang et al. 2013, Gurung et al. 2014, Li et al. 2014, Ouyang et al. 2015, Ehrlich et al. 2017, Hou et al. 2017), although the role of miRNAs in MEN1-associated tumours remains to be established. Therefore to determine if the reported downregulation of miR-15a, miR-16-1 and let-7a in pituitary tumours is a result of loss of menin expression, we investigated the role of menin in the regulation of miR-15a, miR-16-1 and let-7a, using a previously reported murine model of MEN1 (Harding et al. 2009), the mouse pituitary cell line AtT20 and a human cell-based assay that utilised the human cervical adenocarcinoma (HeLa) cell line.

\section{Materials and methods}

\section{Generation of Men1+/- mice}

Animal studies were approved by the University of Oxford Ethical Review Committee and were licensed under the Animal (Scientific Procedures) Act 1986, issued by the United Kingdom Government Home Office Department (PPL30/2914). A conventional Men1-knockout model generated by targeted deletion of exons 1 and 2 of the Men1 allele was used (Harding et al. 2009, Lemos et al. 2009). The $\mathrm{Men}^{+/-}$mice have been reported to develop parathyroid, pancreatic islet, anterior pituitary, adrenal cortical and gonadal tumours (Harding et al. 2009). This model was selected for investigation as greater than $40 \%$ of female mice (over the age of 12 months) develop discrete anterior pituitary tumours readily identifiable at autopsy (Harding et al. 2009). Genotypes of mice 
were determined by PCR analysis using DNA extracted from ear biopsies and Men1 gene-specific primers, as previously reported (Lemos et al. 2009). Primers Men1F (5'-TAGATGTAGCTGGATGGTGATGG-3') and Men1R (5'-ATGAAGCTGAGGAGATGATGTAG-3') yielded a 582 base-pair WT fragment and primers Men1F and NeoR (5'-GCTGACCGCTTCCTCGTG-3') yielded a 809 base-pair mutant fragment (Supplementary Fig. 1A, see section on supplementary data given at the end of this article). The mice were fed a standard diet (Rat and Mouse No. 1 expanded diet, Special Diet Services Ltd.), provided with water ad libitum, and weighed regularly. Pituitaries were isolated from five tumour-bearing female $\mathrm{Men} 1^{+/-}$and five female WT $\left(\right.$ Men1 $\left.{ }^{+++}\right)$mice, aged over 12 months and both maintained on a C57BL/ 6 background, for miRNA analysis. The study was limited to female mice because $<5 \%$ of $\mathrm{Men} 1^{+/-}$males develop pituitary tumours (Harding et al. 2009). The pituitary tumours from $\mathrm{Men} 1^{+/-}$mice in this cohort, as previously reported (Harding et al. 2009), had loss of menin expression, compared to WT pituitaries isolated from Men1+/+ mice (Supplementary Fig. 1B). Both pituitary tumours and WT pituitaries expressed prolactin (Supplementary Fig. 1B).

\section{Cell lines}

Human MEN1-associated pituitary tumour cell lines or normal human pituitary cell lines are not available, and we therefore used the HeLa cell line to investigate the relationship between miR-15a, miR-16-1, cyclin D1 and Men1, as these cells express both miR-15a and miR-16-1, as well as menin and cyclin D1 (Supplementary Fig. 2), and a previous study has mapped the genomic binding sites of menin in these cells (Scacheri et al. 2006). HeLa cells (\#CCL-2) and AtT20 cells (\#CCL-89) were purchased from ATCC and used up to passage eight from the original stock. Both cell lines were maintained in Dulbecco's Modified Eagle medium (DMEM), supplemented with $100 \mathrm{U} / \mathrm{mL}$ penicillin, $100 \mu \mathrm{g} / \mathrm{mL}$ streptomycin, $2 \mathrm{mM}$ L-glutamine and $10 \%$ heat-inactivated foetal calf serum at $37^{\circ} \mathrm{C}, 5 \% \mathrm{CO}_{2}$ and $95 \%$ humidity.

\section{Antagomir transfections}

MicroRNA inhibitors ('antagomirs') to miR-15a and miR-16-1, as well as the control antagomir miR-1, were custom designed and purchased from Thermo Scientific (Table 1). Antagomirs are engineered oligonucleotides that competitively bind to a target miRNA and inhibit their activity. HeLa cells were seeded in six-well plates and transfected with $100 \mathrm{nM}$ antagomirs diluted in serum free DMEM, using Dharmafect 1 transfection reagent (Thermo Scientific). Forty-eight hours post transfection cells were harvested for further analysis.

\section{siRNA transfection}

Cells were seeded in six-well plates and transfected with $25 \mathrm{nM}$ of either control, non-targeting (NT) siRNA or a species specific ON-TARGETplus SMARTpool of siRNAs against MEN1, using Dharmafect 1 transfection reagent (all Thermo Scientific) prepared in serum-free DMEM. After addition of siRNA, cells were incubated for $48 \mathrm{~h}$ and miRNA or protein harvested for further analysis.

\section{Quantitative reverse-transcriptase PCR (qRT-PCR)}

Total RNA, including the miRNA fraction, was extracted from both mouse tissues and cell lines using the mirVana miRNA Isolation Kit (Ambion) according to the manufacturer's instructions, and as previously described (Ma et al. 2007). RNA quality was determined by a NanoDrop ND-1000 Spectrophotometer (NanoDrop Technologies) and agarose gel electrophoresis. Up to $1 \mu \mathrm{g}$ of total RNA was subsequently converted to cDNA using the miScript RT II kit (Qiagen), with HiFlex buffer (Qiagen) and qRT-PCR reactions were performed using the miScript SYBR green kit, according to the manufacturer's instructions, on a Rotor-Gene Q Cycler (Qiagen). Human and mouse-specific miScript primer assays (Qiagen) were purchased for all miRNAs, and human and mouse specific QuantiTect primer assays (Qiagen) for all mRNAs. For all miRNA experiments data was normalised to the small nucleolar reference RNAs RNU6B and SNORD95, and for all mRNA experiments, data were normalised to the control mRNA GAPDH. The relative expression of target CDNA in all qRT-PCR studies was determined using the Pfaffl method, as previously described (Lines et al. 2017).

\section{Western blot}

Cell lines and mouse pituitary tissues were lysed in NP40 lysis buffer: $250 \mathrm{mM} \mathrm{NaCl}$, Tris $50 \mathrm{mM}$ (pH 8.0), $5 \mathrm{mM}$ EDTA, $0.5 \% \mathrm{NP}-40(\mathrm{v} / \mathrm{v})$ and $2 \times$ Protease inhibitor tablets (Roche). Pituitary tissue samples were removed from $-80^{\circ} \mathrm{C}$ storage immediately prior to use and homogenised in an appropriate volume of ice-cold NP40 lysis buffer. Cell lines were washed in PBS and each well lysed in $500 \mu \mathrm{L}$ ice-cold NP40 buffer. Samples were

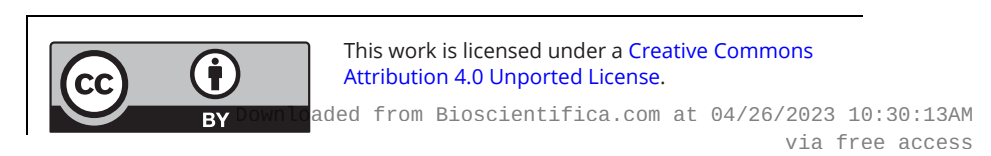


Table 1 Antagomir sequence.

\begin{tabular}{l} 
Antagomir \\
\hline miR-15a \\
miR-1 (Control)
\end{tabular}

\section{Sequence}

$5^{\prime}-\mathrm{mC}\left({ }^{*}\right) \mathrm{mA}\left(^{*}\right) \mathrm{mCmAmAmAmCmCmAmUmUmAmUmGmUmGmCmUmG(*)mC}\left({ }^{*}\right) \mathrm{mU}\left(^{*}\right) \mathrm{mA}\left(^{*}\right)-C h o l-3^{\prime}$

$\left.5^{\prime}-\mathrm{mC}\left(^{*}\right) \mathrm{mG}\left({ }^{*}\right) \mathrm{mCmCmAmAmUmAmUmUmUmAmCmGmUmGmCmUmG(*)mC(*}\right) \mathrm{mU}\left(^{*}\right) \mathrm{mA}\left(^{*}\right)-\mathrm{Chol}^{-3}$ $5^{\prime}-\mathrm{mA}\left(^{*}\right) \mathrm{mU}\left(^{*}\right) \mathrm{mAmCmAmUmAmCmUmUmCmUmUmUmAmCmAmUmU}\left(^{*}\right) \mathrm{mC}\left({ }^{*}\right) \mathrm{mC}\left(^{*}\right) \mathrm{mA}\left(^{*}\right)-\mathrm{Chol}^{\prime} 3^{\prime}$

Specific mature mRNA binding oligonucleotide sequences, antagomirs, were designed to inhibit miR-15a and miR-16-1 activity by preventing the interaction of the miRNA with its mRNA seed sequence. A control miRNA, miR-1, was also designed. All antagomirs contain internal modifications to protect them from RNase-mediated degradation.

(*): Indicates a phosphorothioate linkage; 'm' indicates 2'-O-methyl modified nucleotides; 'Chol' represents a cholesterol group.

incubated on ice for $10 \mathrm{~min}$, centrifuged for $10 \mathrm{~min}$ at $96,000 \mathrm{~g}$ and the supernatant removed for analysis. Lysates were prepared in $5 \times$ Laemmli loading dye: $45 \mathrm{mmol} / \mathrm{L}$ Tris (pH 6.8), 10\% glycerol, $1 \%$ SDS, $50 \mathrm{mmol} / \mathrm{L}$ DTT, $0.01 \%$ bromophenol blue, boiled at $95^{\circ} \mathrm{C}$ for $5 \mathrm{~min}$ and resolved using SDS-PAGE gel electrophoresis. Samples were transferred onto PVDF membrane (PerkinElmer), blocked in 5\% Marvel (powdered-milk) in TBS-T and incubated with 1:100 rabbit anti-cyclin D1 antibody (AbCam), 1:1000 rabbit anti-menin antibody (Bethyl Laboratories) or 1:1000 rabbit anti- $\alpha$-tubulin (AbCam) at $4^{\circ} \mathrm{C}$ overnight. Membranes were subsequently incubated with appropriate HRP-conjugated secondary antibodies and visualised using ECL Western blotting substrate (BioRad) on a BioRad Chemidoc XRS+ system and densitometric analysis performed using Image $\mathrm{J}$, as previously described (Lines et al. 2017).

\section{Histology and immunohistochemistry}

Pituitary tissues were dissected from mice, fixed with $4 \%$ paraformaldehyde, embedded in paraffin, and $4 \mu \mathrm{M}$ sections dewaxed and hydrated for staining, as described (Lines etal. 2017). Sections were stained with haematoxylin and eosin, as previously described (Walls et al. 2016) or used for immunohistochemical staining, in which heatmediated antigen retrieval was performed in citrate buffer and blocking in $10 \%$ donkey serum, before primary antibody incubation. Primary antibodies included rabbit anti-menin (ab2605 (AbCam)), and rabbit anti-prolactin (National Hormone and Pituitary Programme (NHPP)). The secondary antibody was horseradish peroxidaseconjugated goat anti-rabbit (Dako), visualised with a peroxidase/3,3'-diaminobenzidine Envision detection system (Dako). Nuclear counterstaining was performed with haematoxylin QS (Vector Laboratories). Sections were viewed by light or fluorescent microscopy using an Eclipse E400 microscope (Nikon), utilising a DXM1200Cdigital camera and NIS-Elements BR 2.30 software (both Nikon), as described (Lines et al. 2017).

\section{Statistical analysis}

Data were analysed using Students t-test or one-way ANOVA using a Bonferroni correction for multiple comparisons, as previously described (Walls et al. 2012, Gorvin et al. 2013, Lines et al. 2017).

\section{Results}

miR-15a, miR-16-1 and let-7a expression are reduced in $\mathrm{Men1}^{+/-}$mouse pituitary tumours

Quantitative RT-PCR analysis of pituitary tumours isolated from Men1+-- mice or normal pituitary tissue isolated from WT mice, revealed the pituitary tumours, when compared to normal pituitaries, to have a significant decrease in the expression of miR-15a (2.3-fold, $P<0.05)$, miR-16-1 (2.1fold $P<0.01)$ and let-7a $(1.6$-fold $P<0.05)$ (Fig. $1 \mathrm{~A}, \mathrm{~B}$ and C). This observed downregulation of miR-15a, miR16-1 and let-7a in the Men1+/- pituitary tumours was consistent with their reported reduced expressions in human pituitary tumours (Bottoni et al. 2005, 2007, Amaral et al. 2009, Qian et al. 2009, D'Angelo et al. 2012, Palmieri et al. 2012). miR-15a and miR-16-1 are transcribed from the same polycistronic cluster, and an analysis of these miRNAs in the ten individual samples, demonstrated a significant positive correlation between the two miRNAs, consistent with co-transcription $\left(R^{2}=0.77 ; \quad P<0.001\right.$, Fig. 1D).

Decreased expression of miR-15a and miR-16-1 negatively correlates with CCND1 mRNA expression in Men1 ${ }^{+/-}$mouse pituitary tumours

CCND1 is reported to be regulated by miR-15a/miR-16-1 in prostate and non-small-cell lung cancer (Cimmino et al. 2005, Bonci et al. 2008, Calin et al. 2008, Bandi et al . 2009, Croce 2009, Salerno et al. 2009), and we therefore examined CCND1 expression in the pituitary of the Men1 ${ }^{+/-}$mice that had reduced expression of miR-15a and

This work is licensed under a Creative Commons
Attribution 4.0 Unported License.


miR-16-1 (Fig. 1A, B and C). This revealed a significant increase in CCND1 mRNA levels in Men1+/- pituitary tumours $(n=5)$, when compared to normal pituitaries $(n=5)$ from WT mice (2.6-fold, $P<0.0005$, Fig. 2A). These findings were confirmed by Western blot (Fig. 2B) and densitometry analyses (Fig. 2C), which revealed that expression of the cyclin D1 protein was significantly higher (by 4.6-fold to 8.7-fold, $P<0.05-0.005$ ) in the pituitary tumours than in those of the normal pituitaries. Moreover, there was a significant inverse correlation between the levels of CCND1 mRNA and both miR-15a (Fig. 2D, $R^{2}=0.81 ; P<0.0005$ ), and miR-16-1 (Fig. $2 \mathrm{E}, R^{2}=0.78, P<0.001$ ), thereby suggesting that CCND1 mRNA may be under the direct regulation of miR-15a and miR-16-1. Analysis of the expression of a putative let-7a mRNA target, KRAS revealed significantly increased expression of KRAS (by 1.5 fold, $P<0.005$, Supplementary Fig. 3A), in the pituitary tumours of Men1+- mice, when compared to normal pituitaries of Men1 ${ }^{+/+}$mice, although a significant inverse correlation was not observed between the expression of KRAS and let-7a (Supplementary Fig. 3B).
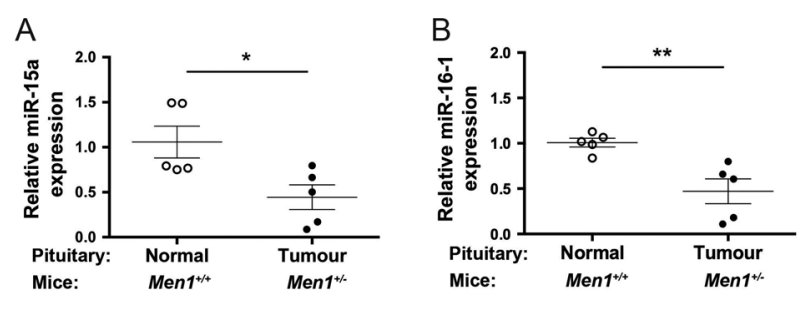

C
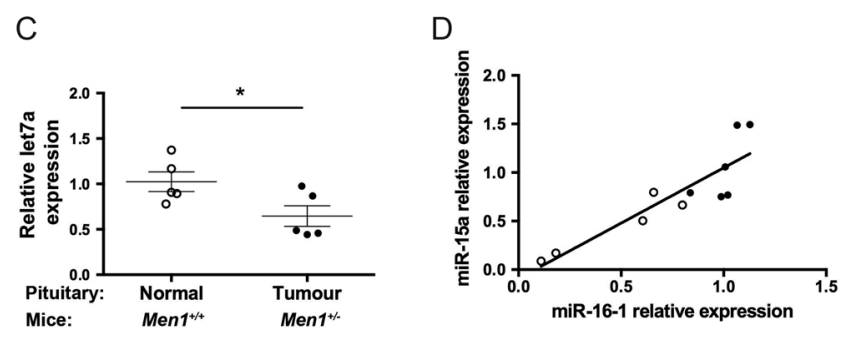

Figure 1

miR-15a, miR-16-1 and let-7a expression in pituitary tumours developing in Men1+/- mice. The expression of miR-15a, miR-16-1 and let-7a was compared in five pituitary tumours (closed circles) from $M e n 1^{+/-}$female mice to five normal pituitaries (open circles) from age- and sex-matched WT Men $1^{+/+}$control mice, using qRT-PCR. The mean and standard error of the mean are shown and samples were normalised to WT, which was set at 1. Expression of miR-15a (A), miR-16-1 (B) and let-7a (C) were each significantly decreased in pituitary tumour samples from Men1+/- mice compared to normal pituitary samples from Men $1^{+/+}$mice; $* P<0.05$, $\star \star P<0.005$. A significant positive correlation was also observed between the relative expression of miR-15a and miR-16-1 in the ten Men1associated pituitary samples (tumour (closed circles) $n=5$, and normal (open circles) $n=5$ ) consistent with transcription from the same polycistronic cluster $\left(\mathrm{D}, R^{2}=0.77, P<0.001\right)$.

\section{Cyclin D1 expression is directly regulated by miR-15a and miR-16-1}

To further analyse the relationship between these miRNAs and cyclin D1, we altered the levels of miR-15a and miR-16-1 in vitro by transfecting HeLa cells with antagomirs that inhibited miR-15a and miR-16-1. Treatment with the miR-15a antagomir significantly decreased expression of miR-15a (14-fold $(P<0.05)$ ), but not miR-16-1 (Fig. 3A), and treatment with the miR-16-1 antagomir significantly decreased miR-16-1 expression (12-fold $(P<0.005)$, but not miR-15a (Fig. 3B). miR-15a and miR-16-1 antagomir treatment also led to significant increases in cyclin D1 expression $(3.1$-fold $(P<0.05)$ and 3.8 -fold $(P<0.005)$, respectively, Fig. $3 \mathrm{C}$ and D). Simultaneous transfection of HeLa cells with antagomirs to both miR-15a and miR-16-1 resulted in similar decreases in expression to that observed with single antagomir transfection (both $P<0.05$, Fig. 3A and $\mathrm{B})$, although the increase in cyclin D1 expression was lower in the co-transfected cells $(2.4$-fold, $P<0.05$, Fig. 3C and D).

\section{Menin regulates the expression of miR-15a}

Menin has been reported to regulate, and to be regulated by miRNAs, including via feedback loops (Luzi et al. 2012a,b, Wang et al. 2013, 2014, Caplin et al. 2014, Gurung et al. 2014, Li et al. 2014, Vijayaraghavan et al. 2014, Lu et al. 2015, Ouyang et al. 2015, Ehrlich et al. 2017, Hou et al. 2017). To determine if there was a feedback loop present between menin and miR-15a/miR-16-1, we examined the effects of antagomir-induced inhibition of miR-15a or miR-16-1 on menin expression in HeLa cells using qRTPCR and Western blot analyses. Antagomirs to miR-15a and miR-16-1 did not alter expression of the MEN1 gene or menin (Fig. 4A and B), indicating that menin expression is not directly regulated by miR-15a or miR-16-1. To assess the possible role of menin in regulating miR-15a or miR-16-1 expression, menin knockdown experiments were performed in human HeLa cells, and in the mouse pituitary cell line AtT20, and miR-15a and miR-16-1 levels analysed using qRT-PCR. Knockdown of menin in HeLa and AtT20 cells, which was confirmed at both the mRNA (both $P<0.0005$, Fig. 4C) and protein levels (Fig. 4D), resulted in a significant decrease in miR-15a expression $(P<0.005$ and $P<0.05$ respectively, Fig. $4 \mathrm{E})$ but not of miR-16-1 (Fig. 4F). miR-15a and miR-16-1 expression are reported to be under the control of a promoter of their host gene, DLEU2 (Lerner et al. 2009), but our analysis of DLEU2 expression following menin knockdown in HeLa

This work is licensed under a Creative Commons Attribution 4.0 Unported License. 
A

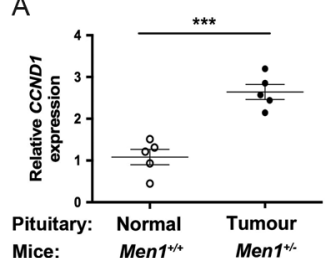

B

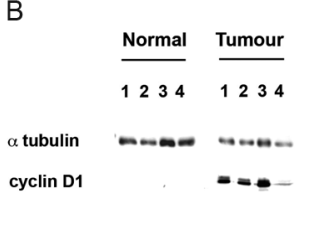

$\mathrm{C}$

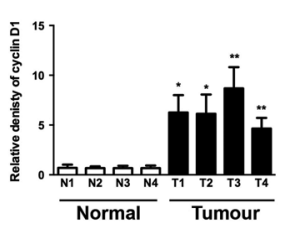

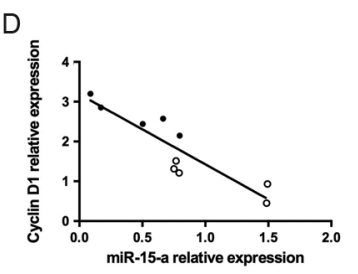

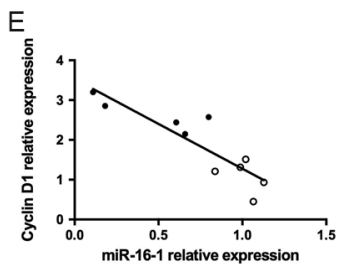

\section{Figure 2}

Correlation of miR-15a and miR-16-1 with CCND1. Analysis of five Men1+/- pituitary tumours (closed circles) and five WT pituitary samples (open circles) by qRT-PCR demonstrated a significant increase in expression of CCND1, a known target of miR-15a and miR-16-1, in the tumour samples (A, $* \star \star P<0.0001)$. Cyclin D1 protein expression, encoded by CCND1, was evaluated in four tumours from Men $1^{+/-}$mice and four normal pituitaries from WT mice $\left(\right.$Men $\left.1^{+/+}\right)$, using Western blot analyses. All four pituitary tumours expressed cyclin D1, whereas cyclin D1 was not detectable in the normal pituitary samples (B). Densitometry analysis of four Western blots confirmed that cyclin D1 expression is significantly higher in the four pituitary tumours (T1-T4 and filled bars) from Men 1+/- mice compared to normal (N1-N4 and open bars) pituitaries from WT (Men $1^{+/+}$mice) $(C, * P<0.05, * \star P<0.005)$. All values were normalised to $\alpha$-tubulin expression. A significant negative correlation was observed in the relative expression of both miR-15a (D) and miR-16-1 (E) compared to CCND1 ( $D, R^{2}=0.81, P<0.0005$ and $\mathrm{E}, R^{2}=0.78, P<0.001$, respectively).

and AtT20 cells revealed that there were no alterations in DLEU2 expression (Supplementary Fig. 4). This finding, which is consistent with the observation that the promoter region of DLEU2 does not contain a meninbinding site (Scacheri et al. 2006), indicates that menin does not appear to regulate the expression of miR-15a by direct binding to the DLEU2 promoter, but instead may influence expression via alternate mechanisms.

\section{Discussion}

Our study has revealed that (1) the expression of the microRNAs miR-15a, miR-16-1 and let-7a are downregulated in pituitary tumours that develop in a Men1+/- mouse model; (2) there is a significant positive correlation between miR-15a and miR-16-1 expression; (3) the decreased miR-15a and miR-16-1 expression is associated with increased cyclin D1 expression and (4) that loss of menin expression is associated with a decrease in miR-15a expression.

The decreased expression of miR-15a, miR-16-1 and let7a in the pituitary tumours of Men $1^{+/-}$mice is in agreement with the reported down regulation of these miRNAs in human pituitary tumours (Bottoni et al. 2005, 2007, Amaral et al. 2009). In addition, the positive correlation between miR-15a and miR-16-1 in the Men1+mouse pituitary tumours (Fig. 1) indicates that these miRNAs are likely transcribed as a polycistronic cluster, under the control of the same promoter elements, as reported for these miRNAs in patients with chronic lymphocytic leukaemia (CLL) (Calin et al. 2008). Moreover, in humans, the miR-15a-miR-16-1 cluster is thought to act as a tumour suppressor and its chromosomal location (13q14) is a site of frequent allelic disruption
A
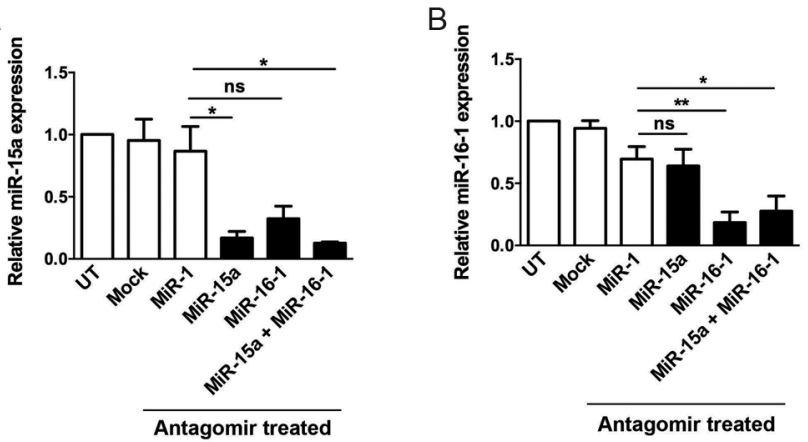

C
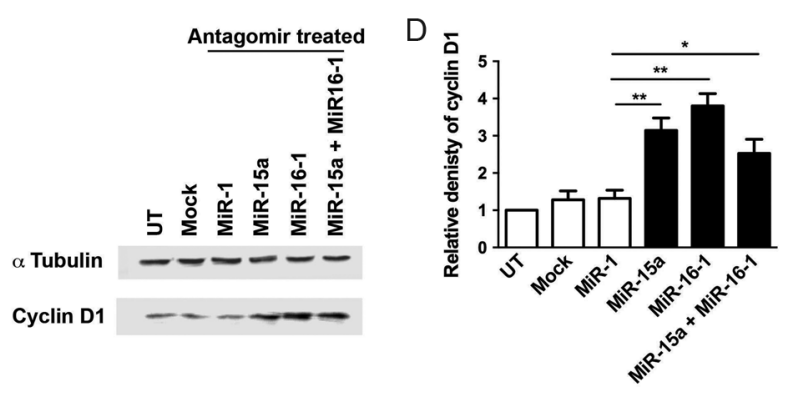

Antagomir treated

\section{Figure 3}

miR-15a and miR-16-1 antagomir treatment increases cyclin D1 expression in human HeLa cells. Inhibition of miR-15a and miR-16-1 binding to their target mRNAs was performed using antagomir transfections in HeLa cells. miRNA-15a levels were significantly reduced when HeLa cells were transfected with antagomirs targeting either miR-15a alone or against both miR-15a and miR-16-1 $\left({ }^{*} P<0.05\right)(\mathrm{A})$. A significant decrease in miR-16-1 levels was also seen when cells were transfected with antagomirs targeting miR-16-1 alone or both miR-15a and miR-16-1 ( ${ }^{*} P<0.05$ and $\left.* * P<0.01\right)$ (B). Forty-eight hours following antagomir transfection the levels of cyclin D1 were assessed using Western blot analyses, and $\alpha$-tubulin was used as a loading control (C). Densitometry analysis of the Western blots $(n=4)$ revealed that cyclin D1 expression was significantly increased following transfection with antagomirs targeting either miR-15a, miR-16-1 alone or in combination $\left({ }^{*} P<0.05,{ }^{*} * P<0.005\right)(\mathrm{D}) . \mathrm{UT}$, untransfected. 
A

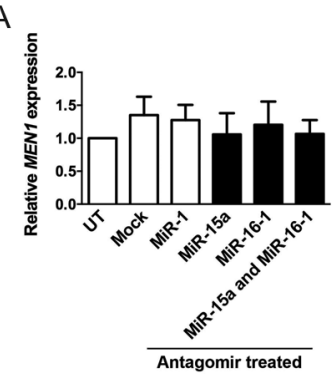

c

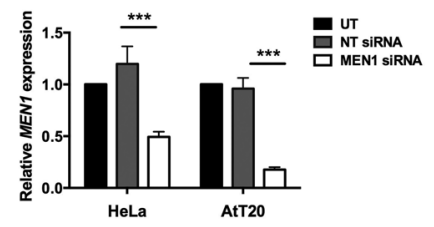

E

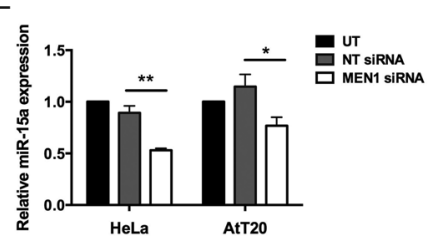

B

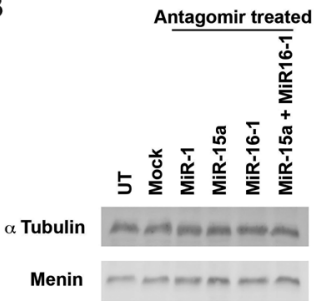

D

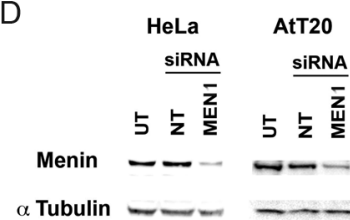

$\mathrm{F}$

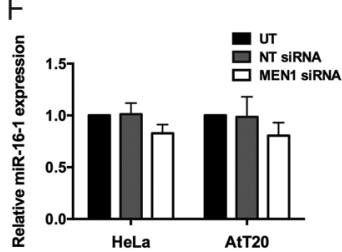

Figure 4

Relationship between miR-15a/miR-16-1 and menin in HeLa and AtT20 cells. Significant differences were not observed in the levels of Men1 or menin expression after antagomir treatment of HeLa cells, evaluated by qRT-PCR (A) and Western blot (B), respectively. Use of MEN1-specific siRNA in HeLa and AtT20 cells decreased expression of MEN1 (C) (assessed by qRT-PCR, $* * * P<0.0005$ ) and menin (D) (assessed by Western blot analysis). The decreased expression of MEN1 and menin, caused by the specific MEN1 siRNA, resulted in a significant decrease in the expression of miR-15a in both HeLa and AtT20 cells ( $\mathrm{E}_{,}{ }^{*} P<0.005$; $\left.* P<0.05\right)$, but not in miR-16-1 expression (F). NT, non-targeting siRNA; UT, untransfected.

or loss in several tumours including CLL, prostate cancer and pituitary tumours where its loss is associated with aggressive features (Pei et al. 1995, Hyytinen et al. 1999, Dong et al. 2001, Calin et al. 2002, 2008). These observations support a role for miR-15a and miR-16-1 in the aetiology of MEN1-associated pituitary tumours.

The observation of increased cyclin D1 protein expression in association with down regulation of miR-15a and miR-16-1 in pituitary tumours from $\mathrm{Men} 1^{+/-}$mice (Fig. 2), suggests that cyclin D1 is a putative target of miR-15a and miR-16-1 in these Men1-associated pituitary tumours. In addition, transfection of HeLa cells with specific antagomirs to miR-15a and miR-16-1 significantly increased cyclin D1 expression (Fig. 3), thereby confirming that cyclin D1 is a likely target of these miRNAs, and this is in agreement with previous human and mouse studies which have reported that cyclin D1 overexpression occurs in a significant proportion of human sporadic pituitary tumours (Gazioglu et al. 2007) and that miR-15a and

miR-16-1 can directly regulate cyclin D1 expression in osteosarcoma and CLL (Salerno et al. 2009, Cai et al. 2012), and that the miR-15a and miR-16-1-binding sites in the 3' UTR of cyclin D1 are highly conserved across species (Deshpande et al. 2009). This negative correlation between the decreased expression of both miR-15a and miR-16-1 and the increased expression of Ccnd1 in Men1associated pituitary tumours (Fig. 2) was not observed to occur between Kras and let-7a (Supplementary Fig. 3). Previous studies of laryngeal and lung cancers have reported that let-7a can regulate the expression of KRAS, and that menin is involved in let-7a miRNA processing (Johnson et al. 2005, Long et al. 2009, He et al. 2010, Oh et al. 2010, Guan et al. 2011, Wang et al. 2013, Gurung et al. 2014). However, our findings suggest that let-7a does not regulate Kras in pituitary tumours of $\mathrm{Men} 1^{+/-}$mice and that it may act via alternative targets.

Menin was found to cause a decrease in miR-15a levels in the pituitary tumours of the Men1+/- mice, and this is similar to reports showing that menin can negatively regulate the expression of miR-26a and miR-29b (Luzi et al. 2012a, Ouyang et al. 2015). In addition, menin has been reported to form a negative feedback loop with miR-24-1, which can mimic the second 'hit' of MEN1 i.e. loss of the second MEN1 allele (Luzi et al. 2012b) and that miRNAs miR-421, miR-24, miR-802, miR-17 and miR-762 can all regulate menin expression (Caplin et al. 2014, Vijayaraghavan et al. 2014, Wang et al. 2014, Lu et al. 2015, Ehrlich et al. 2017, Hou et al. 2017). However, our results, which revealed that antagomirs of miR-15a or miR-16-1 did not affect menin expression (Fig. 4), do not support the existence of a feedback loop between these miRNAs and menin.

We demonstrate that in vitro knockdown of menin in HeLa and AtT20 cells significantly reduced the expression of miR-15a, but not miR-16-1 (Fig. 4). In addition, expression of DLEU2 which is regulated under the same promoter as the miR-15a-miR-16-1 cluster (Lerner et al. 2009) was not altered after menin knockdown (Supplementary Fig. 4). It has previously been reported that in HEK293 cells menin can bind to the arsenite resistance protein (ARS2), which is involved in stabilising capped primary miRNA transcripts and delivering them to the primary miRNA processing complex (Gurung et al. 2014). Furthermore, loss of menin resulted in reduced levels of mature let-7a miRNA, but did not affect primary miRNA levels (Gurung et al. 2014). Therefore, we hypothesise that the loss of menin in the pituitary tumours and cell lines in our study disrupts the activity of ARS2, leading to dysregulation of miR-15a-miR-16-1

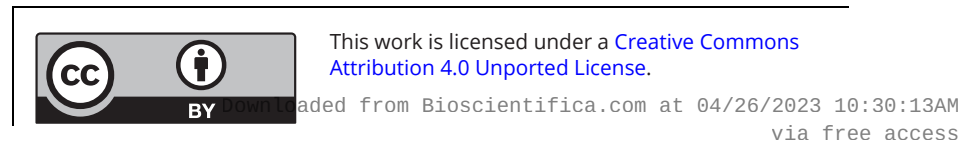


miRNA processing. However, in the tumours from menin null mice we observed a significant decrease in both miR-15a and miR-16-1, expression (Fig. 1); but, in the in vitro menin knockdown studies, we only observed a decrease in miR-15a (Fig. 4). There are two possible explanations for this: first in the in vitro studies, we did not observe complete menin loss as is seen in the Men1 $1^{+/-}$mouse tumours, and therefore the residual menin expression may be attenuating the phenotype or second the menin-null tumours may accumulate additional mutations that can further alter miRNA expression, potentially by modifying the allelic imbalance of miR-15a-miR-16-1 expression, as reported in CLL (Veronese et al. 2015). These studies in CLL have reported that expression of miR-15a and miR-16-1 shows allelic imbalance, with transcription of this cluster being simultaneously regulated by RNA polymerase (RP) II and RPIII mechanisms (Veronese et al. 2015). Thus, miR-15a-miR-16-1 could be transcribed by RPII as a capped primary miRNA sequence or after splicing as an uncapped transcript by RPIII and as ARS2 is involved in stabilising capped primary miRNA transcripts, the menin-ARS2 interaction would only be important for RPII-mediated transcription (Lee et al. 2004, Veronese et al. 2015).

In conclusion, we demonstrate that miR-15a and miR-16-1 are both downregulated in pituitary tumours of Men1 $1^{+-}$mice and that this decrease in expression correlates with an increase in cyclin D1 expression. Moreover, in human cells, inhibition of miR-15a and miR-16-1 binding to mRNA using antagomirs significantly increases cyclin D1 expression, and this may be due to altered processing of miR-15a by menin, as our menin-knockout studies revealed a significant decrease in miR-15a.

\section{Supplementary data}

This is linked to the online version of the paper at https://doi.org/10.1530/ JOE-18-0278.

\section{Declaration of interest}

The authors declare that there is no conflict of interest that could be perceived as prejudicing the impartiality of the research reported.

\section{Funding}

This work was supported by: the UK Medical Research Council grants G9825289, G1000467 (K E L, P J N, M S, R D, R V T) and G0601423 (P J N); AMEND Research Fund Award (K E L); a Wellcome Trust Senior Investigator Award (R V T); Royal Australasian College of Physicians Vincent Fairfax Family Foundation Research Fellowship (C J Y); Australia Awards Endeavour Postgraduate Research Fellowship Award (C J Y); Novartis Pharmaceuticals
Australia Educational Grant (C J Y); Ipsen Pharmaceuticals Australia Educational Grant $(C\lrcorner Y)$ and The Unicorn Foundation Educational Grant (C J Y).

\section{Author contribution statement}

KE L, P J N and R V T designed research; KE L, PJ N, C J Y, M S, R D, G VW and $M R B$ performed experiments; $K E L, P J N$ and $R \vee T$ wrote the manuscript and KE L, P J N , C J Y, M S, R D, G V W, M R B and R V T edited the manuscript.

\section{References}

Amaral FC, Torres N, Saggioro F, Neder L, Machado HR, Silva WA Jr, Moreira AC \& Castro M 2009 MicroRNAs differentially expressed in ACTH-secreting pituitary tumors. Journal of Clinical Endocrinology and Metabolism 94 320-323. (https://doi.org/10.1210/jc.2008-1451)

Bandi N, Zbinden S, Gugger M, Arnold M, Kocher V, Hasan L, Kappeler A, Brunner T \& Vassella E 2009 miR-15a and miR-16 are implicated in cell cycle regulation in a Rb-dependent manner and are frequently deleted or down-regulated in non-small cell lung cancer. Cancer Research 69 5553-5559. (https://doi.org/10.1158/0008-5472.CAN-084277)

Bonci D, Coppola V, Musumeci M, Addario A, Giuffrida R, Memeo L, D'Urso L, Pagliuca A, Biffoni M, Labbaye C, et al. 2008 The miR15a-miR-16-1 cluster controls prostate cancer by targeting multiple oncogenic activities. Nature Medicine 14 1271-1277. (https://doi. org/10.1038/nm.1880)

Bottoni A, Piccin D, Tagliati F, Luchin A, Zatelli MC \& degli Uberti EC 2005 miR-15a and miR-16-1 down-regulation in pituitary adenomas. Journal of Cellular Physiology 204 280-285. (https://doi.org/10.1002/ jcp.20282)

Bottoni A, Zatelli MC, Ferracin M, Tagliati F, Piccin D, Vignali C, Calin GA, Negrini M, Croce CM \& Degli Uberti EC 2007 Identification of differentially expressed microRNAs by microarray: a possible role for microRNA genes in pituitary adenomas. Journal of Cellular Physiology 210 370-377. (https://doi.org/10.1002/jcp.20832)

Cai CK, Zhao GY, Tian LY, Liu L, Yan K, Ma YL, Ji ZW, Li XX, Han K, Gao J, et al. 2012 miR-15a and miR-16-1 downregulate CCND1 and induce apoptosis and cell cycle arrest in osteosarcoma. Oncology Reports 28 1764-1770. (https://doi.org/10.3892/or.2012.1995)

Calin GA, Dumitru CD, Shimizu M, Bichi R, Zupo S, Noch E, Aldler H, Rattan S, Keating M, Rai K, et al. 2002 Frequent deletions and down-regulation of micro-RNA genes miR15 and miR16 at 13q14 in chronic lymphocytic leukemia. PNAS 99 15524-15529. (https://doi. org/10.1073/pnas.242606799)

Calin GA, Cimmino A, Fabbri M, Ferracin M, Wojcik SE, Shimizu M, Taccioli C, Zanesi N, Garzon R, Aqeilan RI, et al. 2008 MiR-15a and miR-16-1 cluster functions in human leukemia. PNAS 105 5166-5171. (https://doi.org/10.1073/pnas.0800121105)

Caplin ME, Pavel M, Cwikla JB, Phan AT, Raderer M, Sedlackova E, Cadiot G, Wolin EM, Capdevila J, Wall L, et al. 2014 Lanreotide in metastatic enteropancreatic neuroendocrine tumors. New England Journal of Medicine 371 224-233. (https://doi.org/10.1056/ NEJMoa1316158)

Chandrasekharappa SC, Guru SC, Manickam P, Olufemi SE, Collins FS, Emmert-Buck MR, Debelenko LV, Zhuang Z, Lubensky IA, Liotta LA, et al. 1997 Positional cloning of the gene for multiple endocrine neoplasia-type 1. Science 276 404-407. (https://doi.org/10.1126/ science.276.5311.404)

Cimmino A, Calin GA, Fabbri M, Iorio MV, Ferracin M, Shimizu M, Wojcik SE, Aqeilan RI, Zupo S, Dono M, et al. 2005 miR-15 and miR-16 induce apoptosis by targeting BCL2. PNAS 102 13944-13949. (https://doi.org/10.1073/pnas.0506654102) 
Concolino P, Costella A \& Capoluongo E 2016 Multiple endocrine neoplasia type 1 (MEN1): an update of 208 new germline variants reported in the last nine years. Cancer Genetics 209 36-41. (https:// doi.org/10.1016/j.cancergen.2015.12.002)

Croce CM 2009 Causes and consequences of microRNA dysregulation in cancer. Nature Reviews Genetics 10 704-714. (https://doi.org/10.1038/ $\operatorname{nrg} 2634)$

D'Angelo D, Palmieri D, Mussnich P, Roche M, Wierinckx A, Raverot G, Fedele M, Croce CM, Trouillas J \& Fusco A 2012 Altered microRNA expression profile in human pituitary GH adenomas: downregulation of miRNA targeting HMGA1, HMGA2, and E2F1. Journal of Clinical Endocrinology and Metabolism 97 E1128-E1138. (https://doi. org/10.1210/jc.2011-3482)

Deshpande A, Pastore A, Deshpande AJ, Zimmermann Y, Hutter G, Weinkauf M, Buske C, Hiddemann W \& Dreyling M 2009 3'UTR mediated regulation of the cyclin D1 proto-oncogene. Cell Cycle $\mathbf{8}$ 3592-3600. (https://doi.org/10.4161/cc.8.21.9993)

Dong JT, Boyd JC \& Frierson HF Jr 2001 Loss of heterozygosity at 13q14 and 13q21 in high grade, high stage prostate cancer. Prostate $\mathbf{4 9}$ 166-171. (https://doi.org/10.1002/pros.1131)

Ehrlich L, Hall C, Venter J, Dostal D, Bernuzzi F, Invernizzi P, Meng F, Trzeciakowski JP, Zhou T, Standeford H, et al. 2017 miR-24 inhibition increases menin expression and decreases cholangiocarcinoma proliferation. American Journal of Pathology 187 570-580. (https://doi. org/10.1016/j.ajpath.2016.10.021)

Filipowicz W, Bhattacharyya SN \& Sonenberg N 2008 Mechanisms of post-transcriptional regulation by microRNAs: are the answers in sight? Nature Reviews Genetics 9 102-114. (https://doi.org/10.1038/ $\operatorname{nrg} 2290)$

Frost M, Lines KE \& Thakker RV 2018 Current and emerging therapies for PNETs in patients with or without MEN1. Nature Reviews Endocrinology 14 216-227. (https://doi.org/10.1038/nrendo.2018.3)

Gazioglu NM, Erensoy N, Kadioglu P, Sayitoglu MA, Ersoy IH, Hatirnaz O, Kisacik B, Oz B, Sar M, Ozbek U, et al. 2007 Altered cyclin D1 genotype distribution in human sporadic pituitary adenomas. Medical Science Monitor 13 CR457-CR463.

Gorvin CM, Wilmer MJ, Piret SE, Harding B, van den Heuvel LP, Wrong O, Jat PS, Lippiat JD, Levtchenko EN \& Thakker RV 2013 Receptor-mediated endocytosis and endosomal acidification is impaired in proximal tubule epithelial cells of Dent disease patients. PNAS 110 7014-7019. (https://doi.org/10.1073/pnas.1302063110)

Goudet P, Murat A, Binquet C, Cardot-Bauters C, Costa A, Ruszniewski P, Niccoli P, Menegaux F, Chabrier G, Borson-Chazot F, et al. 2010 Risk factors and causes of death in MEN1 disease. A GTE (Groupe d'Etude des Tumeurs Endocrines) cohort study among 758 patients. World Journal of Surgery 34 249-255. (https://doi.org/10.1007/s00268-0090290-1)

Guan H, Zhang P, Liu C, Zhang J, Huang Z, Chen W, Chen Z, Ni N, Liu Q \& Jiang A 2011 Characterization and functional analysis of the human microRNA let-7a2 promoter in lung cancer A549 cell lines. Molecular Biology Reports 38 5327-5334. (https://doi.org/10.1007/ s11033-011-0683-8)

Gurung B, Muhammad AB \& Hua X 2014 Menin is required for optimal processing of the microRNA let-7a. Journal of Biological Chemistry 289 9902-9908. (https://doi.org/10.1074/jbc.M113.520692)

Harding B, Lemos MC, Reed AA, Walls GV, Jeyabalan J, Bowl MR, Tateossian H, Sullivan N, Hough T, Fraser WD, et al. 2009 Multiple endocrine neoplasia type 1 knockout mice develop parathyroid, pancreatic, pituitary and adrenal tumours with hypercalcaemia, hypophosphataemia and hypercorticosteronaemia. Endocrine-Related Cancer 16 1313-1327. (https://doi.org/10.1677/ERC-09-0082)

He XY, Chen JX, Zhang Z, Li CL, Peng QL \& Peng HM 2010 The let-7a microRNA protects from growth of lung carcinoma by suppression of k-Ras and c-Myc in nude mice. Journal of Cancer Research and Clinical Oncology 136 1023-1028. (https://doi.org/10.1007/s00432009-0747-5)
Hou R, Yang Z, Wang S, Chu D, Liu Q, Liu J \& Jiang L 2017 miR-762 can negatively regulate menin in ovarian cancer. Onco Targets and Therapy 10 2127-2137. (https://doi.org/10.2147/OTT.S127872)

Hyytinen ER, Frierson HF, Jr., Sipe TW, Li CL, Degeorges A, Sikes RA, Chung LW \& Dong JT 1999 Loss of heterozygosity and lack of mutations of the XPG/ERCC5 DNA repair gene at 13q33 in prostate cancer. Prostate 41 190-195. (https://doi.org/10.1002/(SICI)10970045(19991101)41:3<190::AID-PROS6>3.0.CO;2-2)

Johnson SM, Grosshans H, Shingara J, Byrom M, Jarvis R, Cheng A, Labourier E, Reinert KL, Brown D \& Slack FJ 2005 RAS is regulated by the let-7 microRNA family. Cell 120 635-647. (https://doi. org/10.1016/j.cell.2005.01.014)

Kumar MS, Erkeland SJ, Pester RE, Chen CY, Ebert MS, Sharp PA \& Jacks T 2008 Suppression of non-small cell lung tumor development by the let-7 microRNA family. PNAS 105 3903-3908. (https://doi. org/10.1073/pnas.0712321105)

Lee Y, Kim M, Han J, Yeom KH, Lee S, Baek SH \& Kim VN 2004 MicroRNA genes are transcribed by RNA polymerase II. EMBO Journal $\mathbf{2 3}$ 4051-4060. (https://doi.org/10.1038/sj.emboj.7600385)

Lemmens I, Van de Ven WJ, Kas K, Zhang CX, Giraud S, Wautot V, Buisson N, De Witte K, Salandre J, Lenoir G, et al. 1997 Identification of the multiple endocrine neoplasia type 1 (MEN1) gene. The European consortium on MEN1. Human Molecular Genetics 6 1177-1183. (https://doi.org/10.1093/hmg/6.7.1177)

Lemos MC \& Thakker RV 2008 Multiple endocrine neoplasia type 1 (MEN1): analysis of 1336 mutations reported in the first decade following identification of the gene. Human Mutation 29 22-32. (https://doi.org/10.1002/humu.20605)

Lemos MC, Harding B, Reed AA, Jeyabalan J, Walls GV, Bowl MR, Sharpe J, Wedden S, Moss JE, Ross A, et al. 2009 Genetic background influences embryonic lethality and the occurrence of neural tube defects in Men1 null mice: relevance to genetic modifiers. Journal of Endocrinology 203 133-142. (https://doi. org/10.1677/JOE-09-0124)

Lerner M, Harada M, Loven J, Castro J, Davis Z, Oscier D, Henriksson M, Sangfelt O, Grander D \& Corcoran MM 2009 DLEU2, frequently deleted in malignancy, functions as a critical host gene of the cell cycle inhibitory microRNAs miR-15a and miR-16-1. Experimental Cell Research 315 2941-2952. (https://doi.org/10.1016/j. yexcr.2009.07.001)

Li Y, Li W, Zhang JG, Li HY \& Li YM 2014 Downregulation of tumor suppressor menin by miR-421 promotes proliferation and migration of neuroblastoma. Tumour Biology 35 10011-10017. (https://doi. org/10.1007/s13277-014-1921-1)

Lines KE, Stevenson M, Filippakopoulos P, Muller S, Lockstone HE, Wright B, Grozinsky-Glasberg S, Grossman AB, Knapp S, Buck D, et al. 2017 Epigenetic pathway inhibitors represent potential drugs for treating pancreatic and bronchial neuroendocrine tumors. Oncogenesis 6 e332. (https://doi.org/10.1038/oncsis.2017.30)

Long XB, Sun GB, Hu S, Liang GT, Wang N, Zhang XH, Cao PP, Zhen HT, Cui YH \& Liu Z 2009 Let-7a microRNA functions as a potential tumor suppressor in human laryngeal cancer. Oncology Reports 22 1189-1195.

Lu Y, Fei XQ, Yang SF, Xu BK \& Li YY 2015 Glucose-induced microRNA-17 promotes pancreatic beta cell proliferation through down-regulation of Menin. European Review for Medical and Pharmacological Sciences 19 $624-629$

Luzi E, Marini F, Giusti F, Galli G, Cavalli L \& Brandi ML 2012a The negative feedback-loop between the oncomir Mir-24-1 and menin modulates the Men1 tumorigenesis by mimicking the 'Knudson's second hit'. PLOS ONE 7 e39767. (https://doi.org/10.1371/journal. pone.0039767)

Luzi E, Marini F, Tognarini I, Galli G, Falchetti A \& Brandi ML 2012b The regulatory network menin-microRNA $26 \mathrm{a}$ as a possible target for RNA-based therapy of bone diseases. Nucleic Acid Therapeutics 22 103-108. (https://doi.org/10.1089/nat.2012.0344)

This work is licensed under a Creative Commons Attribution 4.0 Unported License. 
Ma L, Teruya-Feldstein J \& Weinberg RA 2007 Tumour invasion and metastasis initiated by microRNA-10b in breast cancer. Nature 449 682-688. (https://doi.org/10.1038/nature06174)

Mayr C, Hemann MT \& Bartel DP 2007 Disrupting the pairing between let-7 and Hmga2 enhances oncogenic transformation. Science $\mathbf{3 1 5}$ 1576-1579. (https://doi.org/10.1126/science.1137999)

Oh JS, Kim JJ, Byun JY \& Kim IA 2010 Lin28-let7 modulates radiosensitivity of human cancer cells with activation of K-Ras. International Journal of Radiation Oncology Biology Physics 76 5-8. (https://doi.org/10.1016/j.ijrobp.2009.08.028)

Ouyang M, Su W, Xiao L, Rao JN, Jiang L, Li Y, Turner DJ, Gorospe M \& Wang JY 2015 Modulation by miR-29b of intestinal epithelium homoeostasis through the repression of menin translation. Biochemical Journal 465 315-323. (https://doi.org/10.1042/ BJ20141028)

Palmieri D, D'Angelo D, Valentino T, De Martino I, Ferraro A, Wierinckx A, Fedele M, Trouillas J \& Fusco A 2012 Downregulation of HMGA-targeting microRNAs has a critical role in human pituitary tumorigenesis. Oncogene 31 3857-3865. (https://doi.org/10.1038/ onc.2011.557)

Pei L, Melmed S, Scheithauer B, Kovacs K, Benedict WF \& Prager D 1995 Frequent loss of heterozygosity at the retinoblastoma susceptibility gene (RB) locus in aggressive pituitary tumors: evidence for a chromosome 13 tumor suppressor gene other than RB. Cancer Research 55 1613-1616.

Peng Y \& Croce CM 2016 The role of microRNAs in human cancer. Signal Transduction and Targeted Therapy 1 15004. (https://doi.org/10.1038/ sigtrans.2015.4)

Pieterman CR, Schreinemakers JM, Koppeschaar HP, Vriens MR, Rinkes IH, Zonnenberg BA, van der Luijt RB \& Valk GD 2009 Multiple endocrine neoplasia type 1 (MEN1): its manifestations and effect of genetic screening on clinical outcome. Clinical Endocrinology 70 575-581. (https://doi.org/10.1111/j.1365-2265. 2008.03324.x)

Qian ZR, Asa SL, Siomi H, Siomi MC, Yoshimoto K, Yamada S, Wang EL, Rahman MM, Inoue H, Itakura M, et al. 2009 Overexpression of HMGA2 relates to reduction of the let-7 and its relationship to clinicopathological features in pituitary adenomas. Modern Pathology 22 431-441. (https://doi.org/10.1038/modpathol.2008.202)

Salerno E, Scaglione BJ, Coffman FD, Brown BD, Baccarini A, Fernandes H, Marti G \& Raveche ES 2009 Correcting miR-15a/16 genetic defect in New Zealand Black mouse model of CLL enhances drug sensitivity. Molecular Cancer Therapeutics 8 2684-2692. (https:// doi.org/10.1158/1535-7163.MCT-09-0127)
Scacheri PC, Davis S, Odom DT, Crawford GE, Perkins S, Halawi MJ, Agarwal SK, Marx SJ, Spiegel AM, Meltzer PS, et al. 2006 Genomewide analysis of menin binding provides insights into MEN1 tumorigenesis. PLoS Genetics 2 e51. (https://doi.org/10.1371/journal. pgen.0020051)

Stefani G \& Slack FJ 2008 Small non-coding RNAs in animal development. Nature Reviews: Molecular Cell Biology 9 219-230. (https://doi.org/10.1038/nrm2347)

Thakker RV, Newey PJ, Walls GV, Bilezikian J, Dralle H, Ebeling PR, Melmed S, Sakurai A, Tonelli F, Brandi ML, et al. 2012 Clinical practice guidelines for multiple endocrine neoplasia type 1 (MEN1). Journal of Clinical Endocrinology and Metabolism 97 2990-3011. (https://doi. org/10.1210/jc.2012-1230)

Veronese A, Pepe F, Chiacchia J, Pagotto S, Lanuti P, Veschi S, Di Marco M, D'Argenio A, Innocenti I, Vannata B, et al. 2015 Allelespecific loss and transcription of the miR-15a/16-1 cluster in chronic lymphocytic leukemia. Leukemia 29 86-95. (https://doi.org/10.1038/ leu.2014.139)

Vijayaraghavan J, Maggi EC \& Crabtree JS 2014 miR-24 regulates menin in the endocrine pancreas. American Journal of Physiology. Endocrinology and Metabolism 307 E84-E92. (https://doi.org/10.1152/ ajpendo.00542.2013)

Walls GV, Reed AA, Jeyabalan J, Javid M, Hill NR, Harding B \& Thakker RV 2012 Proliferation rates of multiple endocrine neoplasia type 1 (MEN1)-associated tumors. Endocrinology 153 5167-5179. (https://doi.org/10.1210/en.2012-1675)

Walls GV, Stevenson M, Soukup BS, Lines KE, Grossman AB, Schmid HA \& Thakker RV 2016 Pasireotide therapy of multiple endocrine neoplasia Type 1-associated neuroendocrine tumors in female mice deleted for an Men1 allele improves survival and reduces tumor progression. Endocrinology 157 1789-1798. (https://doi.org/10.1210/ en.2015-1965)

Wang YY, Ren T, Cai YY \& He XY 2013 MicroRNA let-7a inhibits the proliferation and invasion of nonsmall cell lung cancer cell line 95D by regulating K-Ras and HMGA2 gene expression. Cancer Biotherapy and Radiopharmaceuticals 28 131-137. (https://doi.org/10.1089/ cbr.2012.1307)

Wang LQ, Chen G, Liu XY, Liu FY, Jiang SY \& Wang Z 2014 microRNA802 promotes lung carcinoma proliferation by targeting the tumor suppressor menin. Molecular Medicine Reports 10 1537-1542. (https:// doi.org/10.3892/mmr.2014.2361)

Wierinckx A, Roche M, Legras-Lachuer C, Trouillas J, Raverot G \& Lachuer J 2017 MicroRNAs in pituitary tumors. Molecular and Cellular Endocrinology 456 51-61. (https://doi.org/10.1016/j.mce.2017.01.021)

Received in final form 25 September 2018

Accepted 28 September 2018

Accepted Preprint published online 28 September 2018 https://joe.bioscientifica.com https://doi.org/10.1530/JOE-18-0278 (c) 2019 The authors Published by Bioscientifica Ltd. Printed in Great Britain

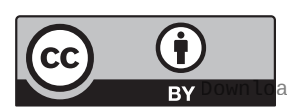

This work is licensed under a Creative Commons Attribution 4.0 Unported License. 